\title{
Synthesis and anion exchange reactions of a layered copper-zinc hydroxy double salt, $\mathrm{Cu}_{1 \cdot 6} \mathrm{Zn}_{0.4}(\mathrm{OH})_{3}(\mathrm{OAc}) \cdot \mathrm{H}_{2} \mathrm{O}$
}

\author{
JACQUELINE THERESE RAJAMATHI, SYLVIA BRITTO and MICHAEL RAJAMATHI* \\ Department of Chemistry, St. Joseph's College, Lalbagh Road, Bangalore 560 027, India \\ e-mail: mikerajamathi@rediffmail.com
}

MS received 16 November 2004; revised 7 March 2005

\begin{abstract}
A mixed-metal hydroxysalt of formula $\mathrm{Cu}_{1 \cdot 6} \mathrm{Zn}_{0 \cdot 4}(\mathrm{OH})_{3}(\mathrm{OAc}) \cdot \mathrm{H}_{2} \mathrm{O}$ has been synthesized by an acetate hydrolysis route. Acetate ions can be exchanged with simple inorganic anions such as chloride and nitrate, and organic anions such as benzoate and large surfactant anions such as dodecyl sulphate. Structures of these hydroxysalts are derived from that of $\mathrm{Cu}_{2}(\mathrm{OH})_{3} \mathrm{NO}_{3} \cdot \mathrm{H}_{2} \mathrm{O}$ with some of the $\mathrm{Cu}^{2+}$ ions being replaced by $\mathrm{Zn}^{2+}$.
\end{abstract}

Keywords. Copper-zinc hydroxides; $\mathrm{Cu}-\mathrm{Zn}$ hydroxysalts; anion exchange.

\section{Introduction}

Layered double hydroxides (LDHs), also known as anionic clays, consist of positively charged layers and charge-compensating anions loosely held in the interlayer region. These solids exhibit unique interlayer chemistry and hence find applications in varied fields such as sorption, catalysis, electrochemistry and photochemistry to cite a few. ${ }^{1}$ These solids undergo anion exchange reactions to yield a variety of functional materials and composites. ${ }^{2}$

Layered hydroxysalts are structurally and functionally related to LDHs closely and may also be brought under the classification of anionic clays. ${ }^{3}$ These can be broadly separated into two structural types, based on the structure of either zinc hydroxynitrate ${ }^{4}$ with the formula $\mathrm{Zn}_{5}(\mathrm{OH})_{8}\left(\mathrm{NO}_{3}\right)_{2} \cdot 2 \mathrm{H}_{2} \mathrm{O}$ or copper hydroxynitrate ${ }^{5,6}$ with the formula $\mathrm{Cu}_{2}(\mathrm{OH})_{3} \mathrm{NO}_{3} \cdot \mathrm{H}_{2} \mathrm{O}$. In $\mathrm{Zn}_{5}(\mathrm{OH})_{8}\left(\mathrm{NO}_{3}\right)_{2} \cdot 2 \mathrm{H}_{2} \mathrm{O}$, a quarter of the octahedral sites in the brucitic layers are vacant and $\mathrm{Zn}^{2+}$ ions occupy the tetrahedral sites on either side of the vacant octahedral sites making the layers positively charged with the composition $\left[\mathrm{Zn}_{3} \square \mathrm{Zn}{ }_{2}(\mathrm{OH})_{8}\right]^{2+}$, where $\mathrm{Zn}$ is in an octahedral site, $\square$ is an octahedral vacancy and $\mathrm{Zn}^{\prime}$ is in a tetrahedral site. ${ }^{4}$ The tetrahedral coordination of $\mathrm{Zn}^{2+}$ ion is satisfied by three hydroxyl ions of the brucitic layer and a water molecule. The positive charge of the layer is compensated for by

\footnotetext{
*For correspondence
}

incorporating anions in the interlayer region. In $\mathrm{Cu}_{2}(\mathrm{OH})_{3} \mathrm{NO}_{3} \cdot \mathrm{H}_{2} \mathrm{O}$ and related systems such as $\mathrm{Ni}_{2}(\mathrm{OH})_{3}\left(\mathrm{NO}_{3}\right) \cdot \mathrm{H}_{2} \mathrm{O}$ the brucitic layers are not positively charged as in the case of zinc hydroxynitrate. Here $25 \%$ of the $\mathrm{OH}^{-}$ions of the $\mathrm{M}(\mathrm{OH})_{2}$ layers are replaced by $\mathrm{NO}_{3}^{-}$ions which are coordinated directly to the metal matrix. ${ }^{7,8}$

Hydroxy double salts are hydroxysalts of the above-mentioned types containing two different metal ions. A number of hydroxy double salts of the zinc hydroxynitrate type have been studied in the past. ${ }^{9,10}$ These solids have been shown to exhibit anion exchange behaviour similar to that of hydrotalcites. In the past attempts have been made to prepare copper zinc hydroxy double salts but these materials have not been well characterised. ${ }^{10}$ Recently, Xue et $a l^{11}$ have reported the synthesis of ktenasite, a copper zinc hydroxysulphate, which is formulated as $\left[\mathrm{Cu}_{3.88} \mathrm{Zn}_{0.78}(\mathrm{OH})_{6 \cdot 32}\left(\mathrm{SO}_{4}\right)_{2}\right]\left[\mathrm{Zn}\left(\mathrm{H}_{2} \mathrm{O}\right)_{6}\right]_{0 \cdot 5} \cdot 0 \cdot 24 \mathrm{H}_{2} \mathrm{O}$. This compound comprises copper hydroxysalt-like layers of the composition $\left[\mathrm{Cu}_{3.88} \mathrm{Zn}_{0.78}(\mathrm{OH})_{6.32}\left(\mathrm{SO}_{4}\right)_{2}\right]^{-}$in which copper and zinc atoms occupy octahedral sites and the sulphate ions are grafted into the layer. To compensate for the negative charge on the layer, hydrated $\mathrm{Zn}^{2+}$ ions are incorporated into the interlayer region.

In this paper, we report the synthesis and anion exchange behaviour of copper zinc hydroxyacetate which derives its structure from that of $\mathrm{Cu}_{2}(\mathrm{OH})_{3}$ $\left(\mathrm{CH}_{3} \mathrm{COO}\right) \cdot \mathrm{H}_{2} \mathrm{O}$ with one fifth of the $\mathrm{Cu}^{2+}$ ions isomorphously substituted by $\mathrm{Zn}^{2+}$ ions. 


\section{Experimental}

$\mathrm{Cu}-\mathrm{Zn}$ hydroxy acetate is prepared by adding solid $\mathrm{ZnO}(0.033$ moles) to $200 \mathrm{ml}$ of an aqueous solution of cupric acetate $(0.050$ moles $)$ with vigorous stirring followed by heating of the resultant mixture at $65^{\circ} \mathrm{C}$ for 2 days with occasional stirring. It should be noted that excessive or prolonged heating results in the formation of copper oxide. The pale blue solid obtained is washed free of ions with distilled water, followed by washing with anhydrous alcohol a few times, then filtered and dried in air at $65^{\circ} \mathrm{C}$. The final alcohol washing is necessary to avoid dehydration leading to copper oxide during prolonged drying. Alternatively, the sample could be dried at room temperature under vacuum.

Interlayer acetate ions are replaced by various anions. About $200 \mathrm{mg}$ of $\mathrm{Cu}-\mathrm{Zn}$ hydroxyacetate is dispersed in $15 \mathrm{ml}$ of $0.25 \mathrm{M}$ aqueous solution of sodium salt of the anion, $\mathrm{A}^{n-}\left(\mathrm{A}^{n-}=\mathrm{Cl}^{-}, \mathrm{NO}_{3}^{-}, \mathrm{C}_{6} \mathrm{H}_{5} \mathrm{COO}^{-}\right.$, $\left.\mathrm{CH}_{3}\left(\mathrm{CH}_{2}\right)_{11} \mathrm{OSO}_{3}^{-}\right)$and stirred for $24 \mathrm{~h}$ at room temperature. The products are washed with deionised water followed by anhydrous alcohol and dried in air at $65^{\circ} \mathrm{C}$.

The materials were characterized by powder $\mathrm{X}$ ray diffraction (Siemens D5005, Bragg-Brentano $\theta$ $2 \theta$ geometry, $\mathrm{CuK}_{\alpha}$ radiation, $4^{\circ} 2 \theta$ per minute), infrared spectroscopy (Nicolet Model Impact 400D FT-IR spectrometer, $\mathrm{KBr}$ pellets, $4 \mathrm{~cm}^{-1}$ resolution) thermogravimetry (a lab-built system, heating rate $5^{\circ} \mathrm{C}$ per minute) and wet chemical analysis. Copper content was estimated gravimetrically using salicylaldehyde oxime. Zinc content was estimated by complexometric titration after removing copper by precipitating it out as its sulphide.

\section{Results and discussion}

The powder X-ray diffraction (PXRD) pattern of the $\mathrm{Cu}-\mathrm{Zn}$ hydroxy acetate is shown in figure 1a. The pattern expanded in the $2 \theta$ region 30-70 degrees is shown in the inset. The powder pattern is similar to that of $\mathrm{Cu}_{2}(\mathrm{OH})_{3}\left(\mathrm{CH}_{3} \mathrm{COO}\right) \cdot \mathrm{H}_{2} \mathrm{O}$ reported earlier by Yamanaka et $a l^{6}$ which implies that the layer structure is related to that of botallackite with the acetate ions being directly coordinated to the $\mathrm{Cu}^{2+}$ or $\mathrm{Zn}^{2+}$ ions. Reflections due to $\mathrm{ZnO}$ are completely absent suggesting that the $\mathrm{Zn}^{2+}$ ions are incorporated in the hydroxysalt structure. The basal spacing is $9.465 \AA$ indicating that the structure is not related to that of ktenasite $^{11}$ whose basal spacing is $11.82 \AA$ even with sulphate, a shorter anion. The pattern could be indexed to a monoclinic cell (similar to copper hydroxyacetate) with the cell parameters $a=5.536 \pm 0.002 \AA$, $b=6 \cdot 141 \pm 0.005 \AA, c=9.447 \pm 0.004 \AA$ and $\beta=$ $94.46 \pm 0 \cdot 03^{\circ}$. The nominal changes in the cell parameters reported for copper hydroxyacetate ${ }^{6}$ suggest partial incorporation of $\mathrm{Zn}^{2+}$ ions in place of $\mathrm{Cu}^{2+}$ ions.

Wet chemical analysis shows the composition as $\mathrm{Cu}=39.6 \%$ and $\mathrm{Zn}=10.3 \%$ leading to the nominal formula $\mathrm{Cu}_{1 \cdot 6} \mathrm{Zn}_{0.4}(\mathrm{OH})_{3}\left(\mathrm{CH}_{3} \mathrm{COO}\right) \cdot \mathrm{H}_{2} \mathrm{O}$. EDXA results are in agreement with this formula. The $[\mathrm{Zn}] /[\mathrm{Cu}]$ ratio is 0.25 in the product and it is less than the $[\mathrm{Zn}] /[\mathrm{Cu}]$ ratio of the reaction mixture which is $0 \cdot 66$, indicating that the reaction is not stoichiometric unlike in the case of the nickel acetate- $\mathrm{ZnO}$ reaction. ${ }^{10}$ Attempts to increase the zinc content by starting with higher $[\mathrm{ZnO}] /\left[\mathrm{Cu}^{2+}\right]$ ratio were unsuccessful as the products turned black due to the formation of $\mathrm{CuO}$.

IR spectra of copper-zinc hydroxyacetate (figure 2a) confirm the presence of acetate ions in the sample.

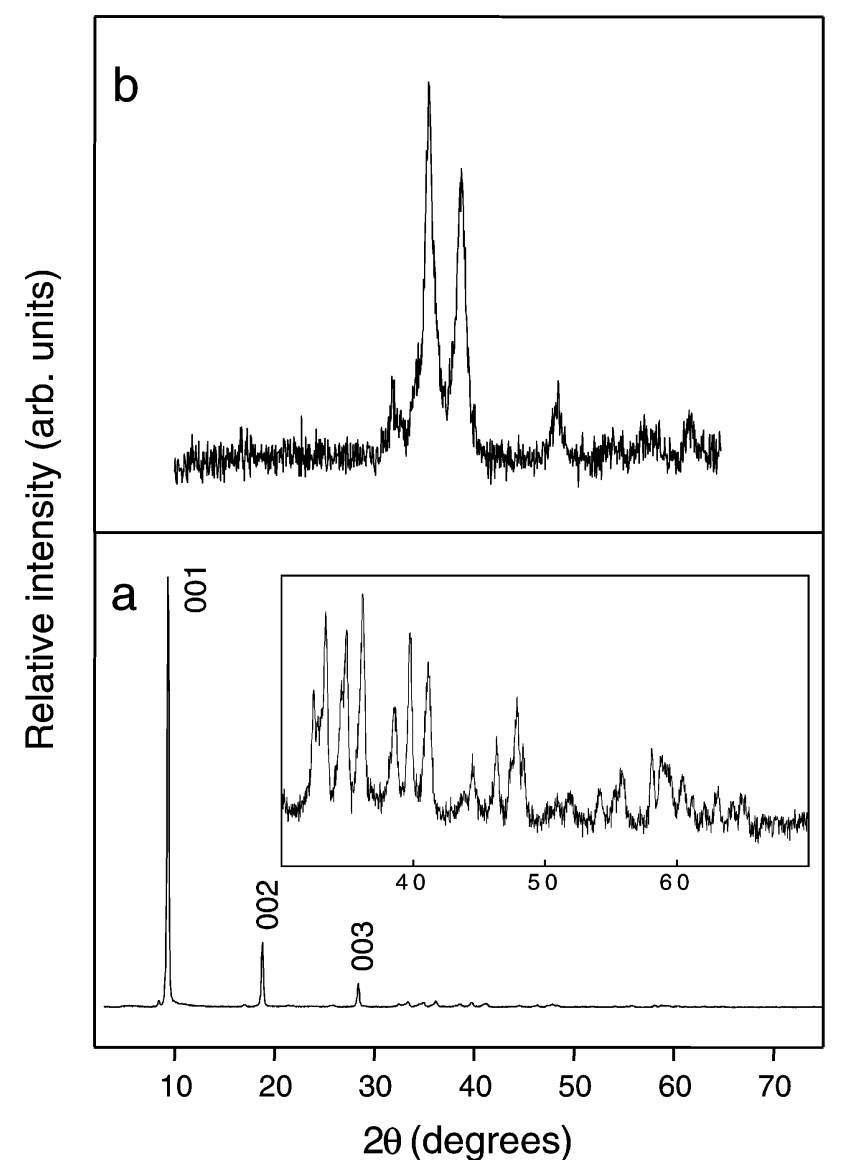

Figure 1. Powder XRD patterns of (a) copper-zinc hydroxyacetate and (b) its thermal decomposition product. 


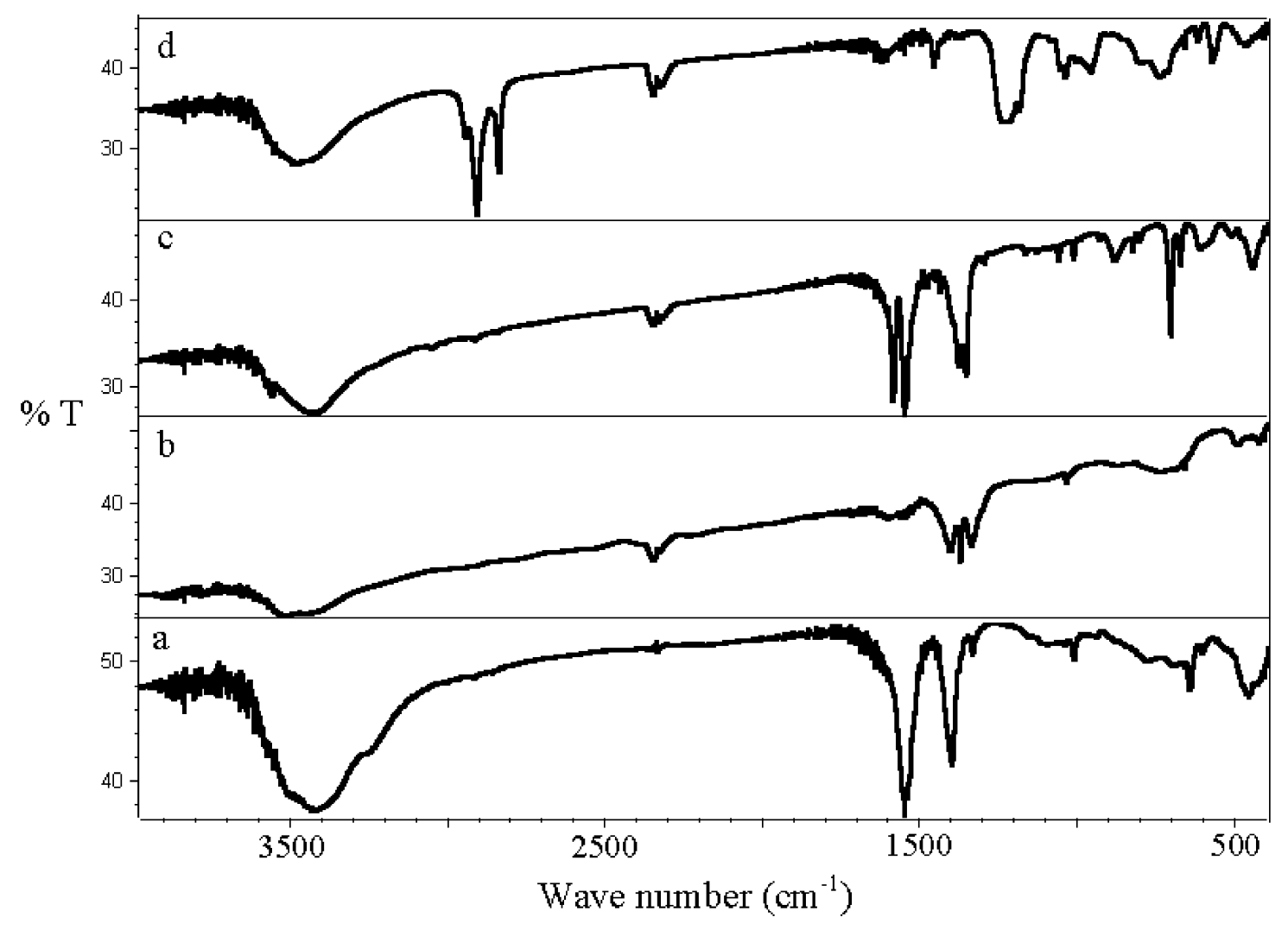

Figure 2. Infrared spectra of copper-zinc hydroxyacetate (a), and its anion-exchanged products obtained by exchanging with nitrate (b), benzoate (c) and dodecyl sulphate $(\mathbf{d})$.

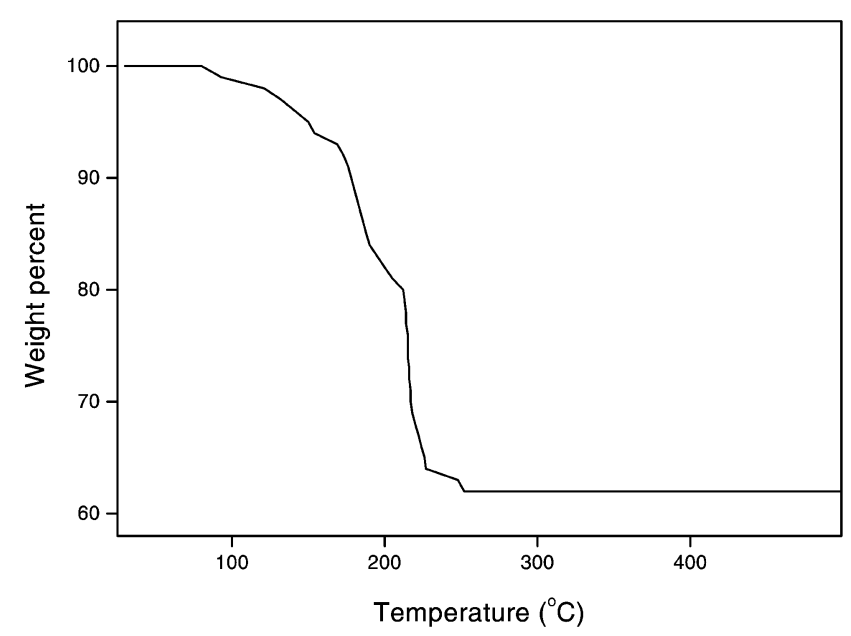

Figure 3. Thermogravimetry curve of copper-zinc hydroxyacetate.

The peaks at 1410 and $1550 \mathrm{~cm}^{-1}$ are due to the stretching vibrations of carboxylate ion and the strong and broad absorption at around $3500 \mathrm{~cm}^{-1}$ is due to the $\mathrm{O}-\mathrm{H}$ stretching vibration of the hydroxyl groups of the brucitic layer and the intercalated water.
Thermogravimetric curves of copper-zinc hydroxyacetate (figure 3 ) show overlapping steps. The first loss $(\sim 7 \%)$ occurs in the range $80-170^{\circ} \mathrm{C}$ and this corresponds to the loss of interlayer water molecules. The unresolved second and third losses observed in the range $170-250^{\circ} \mathrm{C}$ are due to dehydroxylation and decomposition. The net loss observed is $38 \%$, which matches with the proposed formula. The product formed upon decomposition gives a PXRD pattern (figure $1 \mathrm{~b}$ ) matching that of tenorite, while no peaks due to $\mathrm{ZnO}$ are observed. Possibly the oxide is a solid solution with $\mathrm{Zn}$ substituting a fraction of $\mathrm{Cu}$ atoms in the tenorite structure. Such solid solutions have been used as precursors for the syntheses of mixed metal phosphonates. ${ }^{12}$

The $\mathrm{Cu}-\mathrm{Zn}$ hydroxyacetate exhibits anion exchange reactions. Different anions such as chloride, nitrate, benzoate and dodecyl sulphate (DS) may be exchanged for the acetate ions. The PXRD pattern shown in figure $4 \mathrm{a}$ indicates the incorporation of the smaller anion $\mathrm{Cl}^{-}$with the interlayer spacing being $5.66 \AA$. Figure $4 \mathrm{~b}$ shows the PXRD pattern of nitrate-exchanged product with the interlayer spacing $6.99 \AA$ which 
matches with that of $\mathrm{Cu}_{2}(\mathrm{OH})_{3} \mathrm{NO}_{3} \cdot \mathrm{H}_{2} \mathrm{O}$ reported in the literature. ${ }^{5}$ The $d$-spacing is $1.5 \AA$ less than that of an LDH containing interlayer nitrate anions indicating that the $\mathrm{NO}_{3}^{-}$anions are directly coordinated to the $\mathrm{Cu}^{2+} / \mathrm{Zn}^{2+}$ cations of the brucitic layers. The PXRD patterns of benzoate and DS exchanged products are shown in figure $4 \mathrm{c}$ and $\mathrm{d}$ respectively. Here the interlayer spacings are 15.5 and $29.8 \AA$ respectively again, indicating direct grafting of the anion into the layers.

IR spectrum of the nitrate exchanged product shows that the $\mathrm{NO}_{3}^{-}$group is grafted to the matrix cation. The observed bands suggest that the nitrate ion is of $C_{2 v}$ symmetry. Figure $2 \mathrm{~b}$ shows absorption bands at 1424 and $1341 \mathrm{~cm}^{-1}$, which are due to the asymmetric and symmetric $\mathrm{NO}_{2}$ stretching and the absorption at $1052 \mathrm{~cm}^{-1}$ corresponds to $\mathrm{N}-\mathrm{O}$ stretch of the unidentate $\mathrm{O}-\mathrm{NO}_{2}$ group. ${ }^{13,14}$ The sharp peak at $1380 \mathrm{~cm}^{-1}$ is due to free nitrate ions that are produced due to the interaction of the sample with $\mathrm{KBr} .{ }^{15}$ In figure

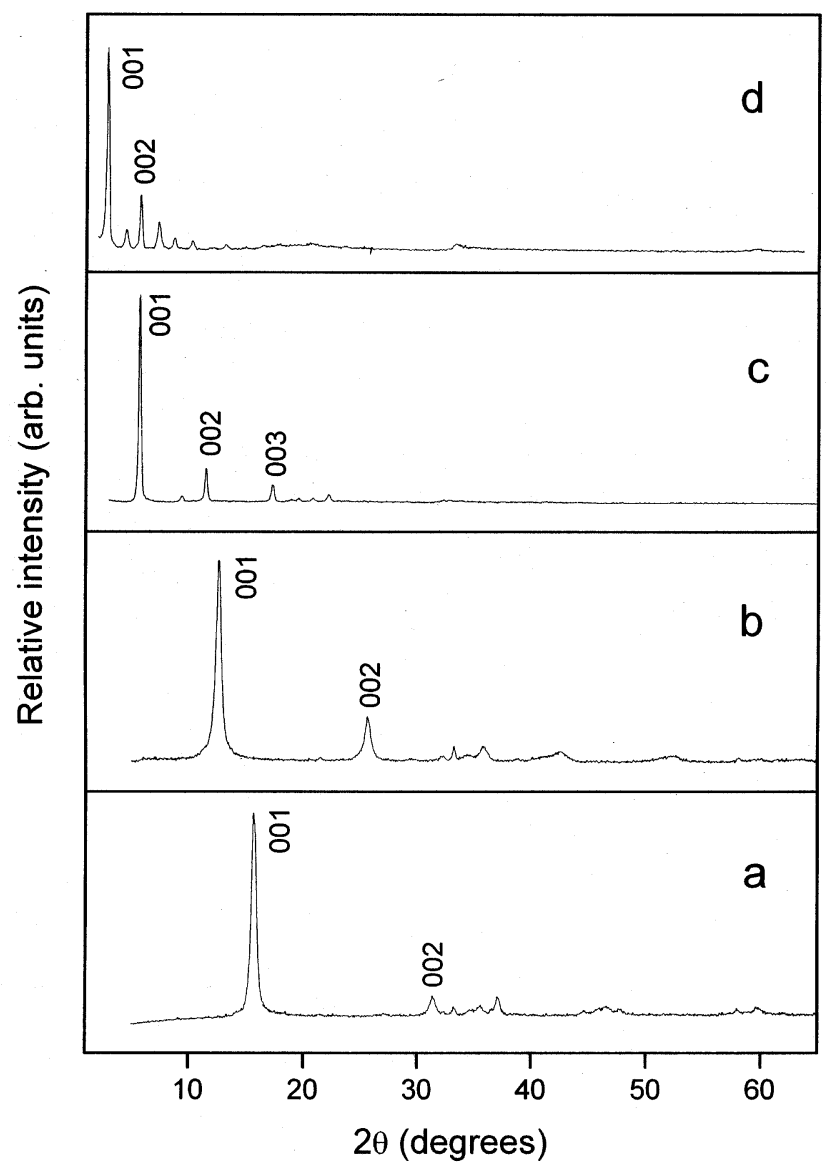

Figure 4. Powder XRD patterns of copper-zinc hydroxysalt ion-exchanged with chloride (a), nitrate (b), benzoate (c) and dodecyl sulphate (d). 2c we show the IR spectrum of the benzoateexchanged product. The absorption bands around 1393 and $1595 \mathrm{~cm}^{-1}$ are due to the carboxylate ion and the absorptions at 1455 and $716 \mathrm{~cm}^{-1}$ are due to $\mathrm{C}=\mathrm{C}$ skeletal in-plane vibration of the aromatic group and $\mathrm{C}-\mathrm{H}$ bending vibration of a monosubstituted benzene ring respectively, ${ }^{16}$ thus confirming incorporation of the benzoate into the solid. In case of DS intercalated product (figure $2 \mathrm{~d}$ ) we observe absorptions at 2920 and $2850 \mathrm{~cm}^{-1}$ due to $\mathrm{C}-\mathrm{H}$ stretching of the alkyl chain of DS and a band at $1260 \mathrm{~cm}^{-1}$ due to the sulphate group. ${ }^{17}$ In all these cases and also the chloride-exchanged product (not shown), acetate-related absorptions are totally absent confirming quantitative ion exchange.

\section{Conclusions}

Copper-zinc hydroxyacetate with partial isomorphous substitution of $\mathrm{Zn}^{2+}$ for $\mathrm{Cu}^{2+}$ ions are synthesized and its other anion analogues obtained through anion exchange reactions. All these solids derive their structures from that of $\mathrm{Cu}_{2}(\mathrm{OH})_{3} \mathrm{NO}_{3} \cdot \mathrm{H}_{2} \mathrm{O}$ with the anions grafted into the layers.

\section{Acknowledgments}

We thank the Department of Science and Technology, New Delhi for funding this work and the Solid State and Structural Chemistry Unit, Indian Institute of Science, Bangalore for PXRD facilities.

\section{References}

1. Cavani F, Trifiro F and Vaccari A 1991 Catal. Today 11173

2. Khan A I and O'Hare D 2002 J. Mater. Chem. 12 3191

3. Rajamathi M, Thomas G S and Kamath P V 2000 Proc. Indian Acad. Sci. (Chem. Sci.) 113671

4. Stahlin W and Oswald H R 1970 Acta Crystallogr. B26 860

5. Newman S P and Jones W 1999 J. Solid State Chem. 14826

6. Yamanaka S, Sako T, Seki K and Hattori M 1992 Solid State Ionics $\mathbf{5 3} 527$

7. Nowacki W and Scheidegger R 1952 Helv. Chim. Acta 375

8. Louer M, Louer D, Delgado A L and Martinez O G 1989 Eur. J. Solid State Inorg. Chem. 26241

9. Meyn M, Beneke K and Lagaly G 1993 Inorg. Chem. 321209

10. Morioka H, Tagaya H, Karasu M, Kadokawa J and Chiba K 1998 J. Mater. Res. 13848 
11. Xue M, Chitrakar R, Sakane K, Ooi K, Kobayashi S, Ohnishi M and Doi A 2004 J. Solid State Chem. 177 1624

12. Menaa B and Shannon I J 2002 Chem.: Eur. J. 84884

13. Addison C C and Gatehouse B M 1960 J. Chem. Soc. 613

14. Gatehouse B M, Livingstone S E and Nyholm R S 1957 J. Chem. Soc. 4222
15. Genin P, Delahyde-Vidal A, Portemer F, TekaiaEhlsissen K and Figlarz M 1991 Eur. J. Inorg. Chem. 28505

16. Dyer J R 1984 Applications of absorption spectroscopy of organic compounds (New Delhi: PrenticeHall of India) pp 30-31

17. Rajamathi J T, Ravishankar N and Rajamathi M 2005 Solid State Sci. 7195 